\author{
Marian Byrka \\ Doctor of Education, Associated Professor, Professor \\ Institute of Postgraduate Pedagogical Education of Chernivtsi region, Department of pedagogy, psychology and \\ education management, Chernivtsy, Ukraine \\ ORCID ID 0000-0002-2891-0044 \\ mbyrka@yahoo.com \\ Andrii Sushchenko \\ Doctor of Education, Professor, Head of Department \\ Classic private University, Department of education and school management, Zaporijja, Ukraine \\ ORCID ID 0000-0003-1659-4280 \\ docanvisu@gmail.com \\ Taras Lukashiv \\ $\mathrm{PhD}$ of Physics and Mathematics, Assistant Professor \\ Yuriy Fedkovych Chernivtsi National University, Chernivtsy, Department of mathematical modeling, \\ Chernivtsy, Ukraine \\ ORCID ID 0000-0002-1651-6402 \\ t.lukashiv@gmail.com
}

\title{
COMPONENTS OF ICT COMPETENCE OF TEACHERS OF MATHEMATICS AND INFORMATICS
}

\begin{abstract}
Nowadays, the competency-based approach is becoming more and more traditional in Ukrainian education for every level - from preschool to postgraduate. Its focus is on two main concepts, "competency" and "competence", interpreted in numerous ways in teaching and learning, which leads to inadequate educational results. Therefore, profound understanding and clear vision of the main concepts are very significant for the effective organization of the educational process. The article examines the ICT competency as a prerequisite for effective professional activities of pre-service teachers of mathematics and informatics in conditions of information society and digital world. The proper ICT competence level can considerably enhance both the teaching and learning processes, facilitate teachers' professional development and their adaptation to changes in educational technologies. In this regard, defining the structure and content of ICT competency of pre-service teachers of mathematics and informatics is very important for clarification of educational process outcomes and students' supporting personal characteristics needed to utilize ICT in their future job. The study introduces the conceptual model of structure of ICT competency and competence, which enlarges the focus of educational process to embrace value orientations and qualities of a person. In our opinion, the structure of ICT competency as well as of ICT competence should include the following criteria: knowledge, skills, habits, value orientations (motives, stimuli, values, interests and ambitions) and person's qualities (abilities). Also, the article discusses the content of ICT competence of pre-service teachers of mathematics and informatics, based on the introduced model. ICT competence content data were acquired from empirical survey that involved students and practicing informatics teachers.
\end{abstract}

Keywords: competency-based approach; ICT competency; ICT competence; content of ICT competence; teachers of mathematics and informatics.

\section{INTRODUCTION}

The problem statement. The ubiquitous information and computer technologies (ICT) lead to changes in the professional requirements to teachers of mathematics and informatics, emphasizing the importance of ICT competencies as a key challenge of information society.

The proper ICT competence level can effectively enhance both the teaching and learning processes, facilitate teachers' professional development and their adaptation to changes in educational technologies. In this regard, defining the structure and content of ICT competence of pre-service teachers of mathematics and informatics is very important for 
clarification of educational process outcomes and students' supporting personal characteristics needed to utilize ICT in their future job.

Analysis of recent studies and publications. The list of works dealing with problems of ICT literacy, teacher ICT competence, and ICT standards and competencies now counts hundreds of titles.

The ICT literacy and its dimensions as a key challenge of the information society have been studied by G. Bogel [1] and M. Wilson, K. Scalise, and P. Gochyyev [2].

The teacher ICT competence and other competencies of the modern teacher have been studied in works [3] - [10]. In particular, scholars have analyzed: the quality of higher education and structure of ICT competence of teachers in Ukrainian high schools (N. Morze, A. Kocharian, and E. Smyrnova-Trybulska) [3], information, communication and informatics competences as components of the system of professional-specialized competences of informatics teacher (O. M. Spirin) [4], ICT competence for secondary school teachers and students in the context of education informatization: global experience and challenges for Ukraine (A. P. Dzhurylo, Ok. M. Shparyk) [5], ICT competence as a basis for teacher's Internet education (A. Elizarov) [6], modern studies and prospects of information and communication competence development in education system (O. Ovcharuk, N. Soroko) [7], the competencies of the modern teacher (O. Nessipbayeva) [8], ICT competencies of future teachers of mathematics and informatics (E. Valavičius, V. Jadzgevičiene) [9], the model of teachers' ICT competence (N. Morze, I. Vorotnykova) [10].

Several publications were devoted to different aspects of teacher's ICT standards, competencies and assessing teacher's ICT competence: policy framework of ICT competency standards for teachers [11], national educational technology standards for teachers [12], assessing the ICT competence of teachers in accordance with the requirements of "Teacher" occupational standard (S. Avdeeva, O. Zaichkina, N. Nikulicheva and S. Khapaeva) [13], certification programs for training teachers in the ICT use (J. Briceño Martínez, M. Castellanos Saavedra) [14], and independent certification of a teacher's ICT competence (M. Weindorf-Sysoeva, S. Hapaeva) [15].

However, the conducted studies mostly concentrate on teacher's knowledge and skills as main parts of ICT competence.

The article's purpose is threefold: first, to analyze the genesis of competency-based approach in education and its main concepts; second, to introduce a conceptual model of the structure of ICT competency and competence; and third, to illustrate the content of ICT competency of pre-service teachers of mathematics and informatics, based on this model with the aim of implementation of obtained results in higher education practice.

\section{RESEARCH METHODS}

The research was conducted using a qualitative and inductive research plan with all appropriate ethical concerns taken into consideration to comply with the norms and standards of the field. The following theoretical methods were used in the research methodology: critical analysis of philosophical, psychological and pedagogical sources on the genesis of the competency-based approach in education and its main concepts; conceptualization of the notions "ICT competency" and "ICT competence"; modelling of the structure of ICT competency and competence; study of the content of ICT competence through the questioning of pre-service teachers of mathematics and informatics and practicing informatics teachers; involving experts in the process of analyzing the obtained raw data on the content of ICT competence; illustration of the content of ICT competence of pre-service teachers of mathematics and informatics, based on this model.

The empirical surveys were conducted among fourth-year students of the Mathematics 
and Informatics Faculty of Yuriy Fedkovych Chernivtsi National University (YFCNU), and among practicing informatics teachers who attended training courses at the Institute of Postgraduate Pedagogical Education of Chernivtsi region (IPPECE). A total of 136 people took part in the first survey, 79 people in the second survey, and 10 experts were involved to process raw data obtained from the first survey.

\section{THE THEORETICAL BACKGROUNDS}

\subsection{The genesis of the competency-based approach in education}

Although competency-based approach in education has gained significant attention in recent studies and education policies, it is not a new concept either for the educational system of Ukraine or for educational systems of other countries, as it changes only the focus of learning, outlining what graduates should be able "to do" rather than what they should "know". In other words, skills are more important than knowledge.

The genesis of competency-based approach in education is associated with U.S. efforts to reform teacher education and vocational education training in the 1960s. Further it has developed to more robust and complex models of learning in all levels of education [16].

In Ukraine, it has evolved from knowledge, skills and habits approach and personalitybased approach.

The knowledge, skills and habits approach was used in Ukrainian education system in the period from 1991 to 2000. It is the legacy of the former Soviet Union system of education. According to this approach, the main criteria of students' academic performance were knowledge, skills and habits as well as a certain level of practical training, which pre-service teachers achieved through short-term pedagogical practice, conducted in school. However, this approach led to overloading the learning material with extra information. Despite disadvantages, today the ideas of the knowledge, skills and habits approach are not completely rejected, since the main achievements in learning are still knowledge, skills and habits.

Since the 2000s, the Ukrainian education system has been implementing a personalitybased approach. The main idea of this approach is the consideration of each student as a personality. Such position provides for the learner a freedom to choose the content of education according to educational, spiritual, cultural and life needs of an individual student, forming their personality and offering possibilities of self-realization in educational and cultural space. It should be noted that the personality-based approach does not reject the above mentioned criteria (knowledge, skills and habits), but adds to them two more - value orientations and person's qualities (abilities). Value orientations include motives, stimuli, values, interests and ambitions. At the same time, assessment of students' achievements is made by three main criteria - knowledge, skills and habits, while others are taken into account during the organization of the educational process. Based on this approach, scholars and policy makers began to incorporate into the educational process such new items as creative activity, communication and interaction, in order to ensure the formation of an integral person. Also the content of education included some physical and intellectual characteristics (health, ability to think, feel, act), social skills and cultural values (freedom, humanity, spirituality, creativity) etc.

Since 2010, the key role in Ukrainian educational system has belonged to the competency-based approach, which is based on the idea of orienting the learning process towards some particular activity of a student. Also, it declares the higher value of skills in comparison with knowledge as a result of learning. The focus of competency-based approach is on a person's "competency" and "competence". 
These concepts have been interpreted in numerous ways in latest studies. For example, in [17] "competency" is defined as "a specific area, a range of activities, a predetermined system of issues of which the person should be well aware, a certain set of knowledge, skills, and attitudes to them", and "competence" is defined as "a quality of a person, his or her certain attribute, which is based on knowledge, experience, and moral principles".

In the work [18] "competency" is considered as "an objective category, a socially recognized level of knowledge, skills, and attitudes in a specific field of human activity as an abstract medium", and "competence" is interpreted as "an integrated characteristic of personality's quality, a resultant block formed through experience, knowledge, abilities, attitudes, and behavioral responses".

In [19], the term "competency" is defined as "a set of individual performance behaviors which are observable, measurable and critical to successful individual and company performance; attributes, required of a person to achieve competent performance", and "competence" as "individual characteristics of a person which result in an effective and superior performance in a job; the outputs, or results of training".

In our opinion, the term "competency" means requirements to a person that are necessary for successful implementation of a particular activity (a scale), and "competence" means a measure of person's compliance with these requirements (level on the scale).

Regardless of short lifetime of competency-based approach in Ukraine, competency frameworks have been implemented at the national, institutional, and program levels as a main concept of educational system reforms.

For instance, according to the Law of Ukraine "On education", the aim of higher education for a person is "acquisition of a high level of scientific and/or creative artistic, professional and general competencies required for work in a certain specialty or in a particular field of knowledge" [20].

\subsection{The concept of the structure of ICT competency and ICT competence}

The effective implementation of competency-based approach in Ukrainian education largely depends on clear and profound understanding of its main categories, since misinterpreting of competency, competence, and their structure causes inadequate results of education and training.

Therefore, we present our concept of the structure of the main categories of competency-based approach in education in the ICT context. The structure of ICT competency as well as of ICT competence should include the following criteria: knowledge, skills, habits, value orientations (motives, stimuli, values, interests and ambitions) and person's qualities (Fig. 1). In this figure, person's qualities act as profound background for education, value orientations boost this process, and knowledge, skills, and habits are the results of education.

We consider that recognizing and rewarding only value orientations or person's separate qualities provide a strong basis for student engagement in education process; however, their combination gives much better results. 


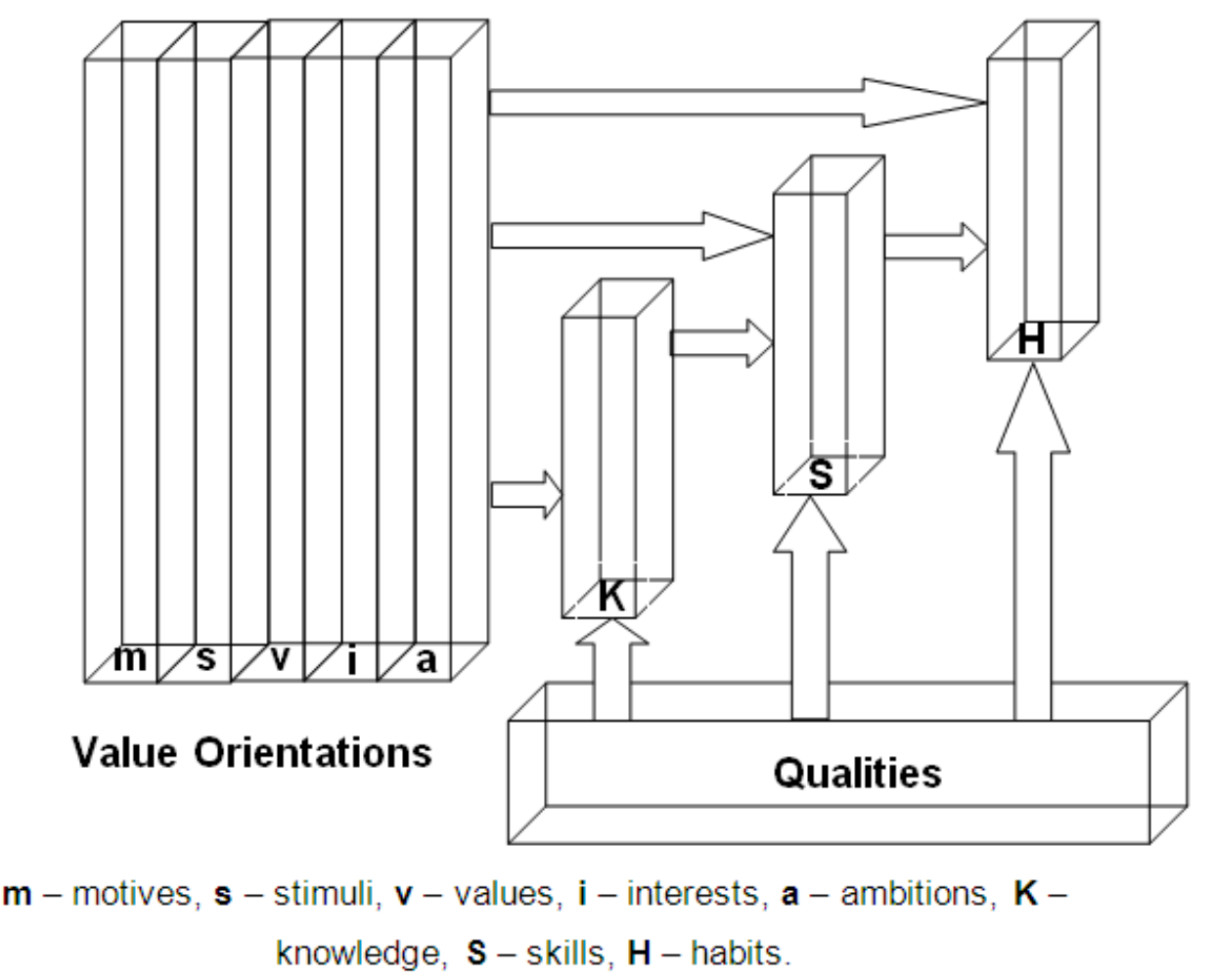

Figure1. The conceptual model of the structure of ICT competency and competence

The proposed conceptual model of the structure of ICT competency and ICT competence is more advanced, flexible and stable, because it takes into account value orientations and qualities of a person as the important variables of teaching and learning. Here knowledge, skills and habits are the most variable components, for the reason that they depend on fast enhancement and developing of a new ICT in information society.

\section{THE RESULTS AND DISCUSSION}

\subsection{Stage 1. Collecting raw data on the content of ICT competency of pre-service teachers of mathematics and informatics}

The first stage of the experiment was carried out in 2017-2018 on the basis of IPPECE and Faculty of Mathematics and Informatics of YFCNU. Its purpose was to determine the content of the core characteristics of the ICT competency of teachers of mathematics and informatics, namely: value orientations (motives, stimuli, values, interests and ambitions) and person's qualities (abilities).

The empirical survey was conducted among 75 practicing informatics teachers who attended training courses at IPPECE, and among 61 pre-service teachers of mathematics and informatics (fourth-year students) of the Mathematics and Informatics Faculty of YFCNU. A questionnaire was developed for the survey "Determining the importance of personality characteristics needed for effective use of ICT in professional activities", which contains seven open-end questions to respondents.

Table 1 presents the questions of the questionnaire and respondents' generalized answers by categories "teachers of mathematics and informatics" and "practicing informatics teachers". 


\section{Questions and respondents' generalized answers by category}

\begin{tabular}{|c|c|}
\hline $\begin{array}{l}\text { Pre-service teachers of mathematics and } \\
\text { informatics }\end{array}$ & Practicing informatics teachers \\
\hline \multicolumn{2}{|c|}{ 1. What motives are important for the use of ICT in professional activities? } \\
\hline 1. Acquisition of new information technologies & 1. Acquisition of new knowledge \\
\hline 2. Availability & 2. Being a professional \\
\hline 3. Cognitive and educational motives & 3. Cognitive \\
\hline 4. Cost saving & 4. Enhancing possibilities \\
\hline 5. Development of creativity & 5. Enhancing the quality of work \\
\hline 6. Development of critical thinking & 6. Personal \\
\hline 7. Development of personal abilities & 7. Professional development \\
\hline 8. Development of science & 8. Satisfaction from achieving the goal \\
\hline 9. Enhancing productivity & 9. Self development \\
\hline 10. Flexibility & 10. Self improvement \\
\hline 11. Future employment & \\
\hline 12. Improving the efficiency of professional activities & \\
\hline 13. Improving the level of qualification & \\
\hline 14. Improving your own professionalism & \\
\hline 15. Increasing the speed of implementation & \\
\hline 16. Individual personal development & \\
\hline 17. More opportunities & \\
\hline 18. Optimization & \\
\hline 19. Personal interest in ICT & \\
\hline 20. Possibility of self-expression & \\
\hline 21. Productive use of teaching materials & \\
\hline 22. Responsibility & \\
\hline 23. Support for interest in professional activities & \\
\hline 24. Support for interest in learning & \\
\hline 25. Teacher self-education & \\
\hline $\begin{array}{l}\text { 26. The desire to always learn } \\
\text { 27. The desire to be modern }\end{array}$ & \\
\hline 28. The desire to evolve & \\
\hline 29. The desire to go to the set goal & \\
\hline 30. The desire to identify personal weaknesses in a & \\
\hline \multicolumn{2}{|c|}{ 2. What stimuli encourage you to use ICT in your professional activities? } \\
\hline 1. Additional emotional and intellectual stimuli & 1. Complications of the professional activity that \\
\hline 2. Career growth & require enhancement of knowledge and skills \\
\hline 3. Cognition of new knowledge & 2. Financial stimuli \\
\hline 4. Communication & 3. Improving the perception of information by the \\
\hline 5. Competitiveness & audience \\
\hline 6. Cost saving & 4. Making professional work less effort- \\
\hline 7. Development of responsibility & consuming. \\
\hline 8. Financial stimuli & 5. Social stimuli \\
\hline 9. Improvement of qualification & 6. To interest students \\
\hline 10. Improving the quality of education & \\
\hline 11. Independence & \\
\hline 12. Public opinion & \\
\hline 13. Qualitative understanding of the material & \\
\hline 14. Requirements of the profession & \\
\hline 15. Competitiveness & \\
\hline 16. Self development & \\
\hline 17. The desire to create & \\
\hline 18. The desire to succeed & \\
\hline 19. The importance of ICT in the modern world & \\
\hline 20. Timesaving & \\
\hline
\end{tabular}


3. What values are important for the use of ICT in professional activities?

1. Concentration

2. Formation of a public position

3. Getting experience

4. Harmonious development

5. Improving the effectiveness of learning

6. Independence

7. Material values

8. Mutual understanding

9. Personal growth

10. Possibility of self-realization

11. Self-awareness

12. Spiritual values

13. Successful self-realization in society

\author{
Cultural values \\ 2. Health \\ 3. Informational values \\ 4. Legal values \\ 5. More resources \\ 6. Personal values \\ 7. Professional values \\ 8. Respect for the rights and obligations \\ 9. Social values
}

4. What interests are important for the use of ICT in professional activities?

1. Acquiring new information

2. Cognitive interests

3. Communication

4. Creating favorable conditions for the identification and development of students' abilities

5. Development of society

6. Extending the teacher's possibilities

7. Improving the quality of education

8. Love for computer science

9. Professional interests

10. Self improvement
1. Aesthetic interests

2. Economical interests

3. Indirect interests

4. Interest to be modern

5. Personal interests

6. Political interests

7. Professional interests

8. Scientific interests

9. Study and introduction of innovations

10. To carry out work quickly and qualitatively 5. What are your intentions and ambitions to use ICT in professional activities?

1. Convenient information format

2. Formation of student's informational culture

3. Improving the efficiency of professional activities

4. Improving personal knowledge

1. Class engagement

2. Better perception of the material

3. Self development

4. To be modern

5. Quick access to information

6. To make my work less effort-consuming

7. The intention to intensify the student's research

8. The intention to interest students

9. The need for constant updating of knowledge about the possibilities of ICT

10. To clearly understand the tasks and find the best ways to solve them

\section{What personal qualities are important for the use of ICT in professional activities?}

1. Activity

2. Communicativeness

3. Concentration

4. Confidence in the correctness of making nonstandard decisions

5. Conscious attitude to learning

6. Constancy of character

7. Being up-to-date

8. Creativity

9. Education

10. Thoroughness

11. Good eyesight

12. Hard work

13. Purposefulness

14. Responsibility

15. Self-confidence

1. Analytical abilities

2. Attentiveness

3. Communicativeness

4. Courage

5. Self-discipline

6. Determination

7. Hard work

8. Impartiality

9. Initiative

10. Objectivity

11. Observation

12. Perseverance

13. Purposefulness

14. Responsibility

15. Wider horizons

16. Will

16. Self-realization

17. Vibrant fantasy

7. What capabilities and inclinations are necessary for effective use of ICT in professional activities? 


\begin{tabular}{|l|l|}
\hline 1. Abstract thinking & 1. Thinking about the image \\
2. Activity & 2. Intellectual abilities \\
3. Thoroughness & 3. Logical thinking \\
4. Inclination towards science and technology & 4. Programming \\
5. Intellectuality & \\
6. Logical thinking & \\
7. Mathematical abilities & \\
8. Memory and attention & \\
9. Organizational abilities & \\
10. Responsibility & \\
11. Tolerance & \\
12. Willpower & \\
\hline
\end{tabular}

\subsection{Stage 2. Processing of obtained raw data on the content of ICT competence of pre-service teachers of mathematics and informatics by experts}

Due to using open-ended questions in the survey, the aim of the second stage of our experiment was to eliminate respondents' wrong, incompatible and unaccounted answers, obtained from the first survey.

For this purpose, 10 experts were asked to process the collected raw data of the first stage of the experiment. Five of them were from IPPECE and five were from YFCNU, Department of Mathematical Modelling.

The experts were asked to select items that are appropriate for the relevant criteria. Each item was assessed on the five-point scale: +2 - "completely suitable", +1 - "suitable", 0 "hard to answer", -1 - "not suitable", and - 2 - "completely not suitable". As a result of the second stage, from 3 to 10 items which received the lowest score, were discarded.

Finally, we obtained a valid questionnaire, which will be used to further define the top ten core characteristics of the content of ICT competency of pre-service teachers of mathematics and informatics.

\subsection{Stage 3. Top characteristics of the content of ICT competence of pre-service teachers of mathematics and informatics}

The aim of the third stage of the experiment was to determine top ten core characteristics of the ICT competence of pre-service teachers of mathematics and informatics in each of the criteria.

This stage was carried out on 2018-2019 among 79 pre-service teachers of mathematics and informatics (fourth-year students) of the Mathematics and Informatics Faculty of YFCNU in the form of a rating scale questions (1 to 10).

The questionnaire contains from 14 to 40 characteristics on 7 criteria of ICT competence, namely: motives, stimuli, values, interests, intentions and ambitions, qualities, capabilities and inclinations of a person.

Consequently, we obtained the following results for each criterion.

The top ten motives for pre-service teachers of mathematics and informatics that are important for the use of ICT in professional activities are:

1. Becoming a professional

2. Improving the efficiency of professional activities

3. Development of personal abilities

4. Acquiring new knowledge

5. Professional development

6. The desire to be modern

7. Productive use of teaching materials

8. Improving the level of qualification 
9. More opportunities

10. Possibility of self-expression

Among the top ten stimuli that encourage pre-service teachers of mathematics and informatics to use ICT in professional activities are:

1. Requirements of the profession

2. Career growth

3. Improvement of qualification

4. Competitiveness

5. Cost savings

6. Time saving

7. Independence

8. Public opinion

9. Making work in class less effort-consuming.

10. Development of responsibility.

The top ten values for pre-service teachers of mathematics and informatics that are important for the use of ICT in professional activities are:

1. Getting experienced

2. More resources

3. Harmonious development

4. Improving the effectiveness of learning

5. Concentration

6. Self-awareness

7. Mutual understanding

8. Formation of a public position

9. Possibility of self-realization

10. Successful self-realization in society.

Among the top ten interests that encourage pre-service teachers of mathematics and informatics to use ICT in professional activities are:

1. Communication

2. Self improvement

3. Acquiring new information

4. Study and introduction of innovations

5. Creating favorable conditions for the identification and development of students' abilities

6. To carry out work quickly and qualitatively

7. Extending the teacher's possibilities

8. Improving the quality of education

9. Economic interests

10. Professional interests.

The top ten intentions and ambitions pre-service teachers of mathematics and informatics have concerning the use of ICT in professional activities are:

1. Quick access to information

2. Making professional work less effort-consuming

3. Improving personal knowledge

4. Improving the efficiency of professional activities

5. Class engagement

6. Better perception of the material

7. The intention to interest students

8. The intention to intensify students' research.

9. Formation of students' information culture 
10. Convenient information format.

The top ten personal qualities that are important for the use of ICT in professional activities by pre-service teachers of mathematics and informatics are:

1. Analytical abilities

2. Conscious attitude to learning

3. Self-discipline

4. Communicativeness

5. Purposefulness

6. Being up-to-date

7. Initiative

8. Concentration

9. Responsibility

10. Self-confidence.

The top ten capabilities and inclinations that are necessary for effective use of ICT in professional activities for pre-service teachers of mathematics and informatics are:

1. Logical thinking

2. Accuracy

3. Willpower

4. Memory and attention

5. Activity

6. Responsibility

7. Inclination towards sciences and technology

8. Mathematical abilities

9. Intellectual abilities

10. Abstract thinking.

\section{CONCLUSIONS AND PROSPECTS FOR FURTHER RESEARCH}

In the ICT context, the aim of competency-based approach is to develop ICT competence, which is treated as a result of a student's learning activities. However, the structure and content of ICT competence have different definitions, mostly focused on student's knowledge and skills. Such situation increases possibility to gain inadequate results of education and training, because knowledge and skills are strictly dependent on the appearance of new ICT, changes of information society and therefore are very fluent.

Our concept is based on the opinion that the structure of ICT competence, besides knowledge and skills, should include: habits, value orientations (motives, stimuli, values, interests and ambitions) and person's qualities (abilities). In the concept, person's qualities act as a profound background for the person's education, and value orientations act as a booster of this process, whereas knowledge, skills, and habits traditionally are considered as results of education.

In our opinion, separate consideration of a person's qualities and value orientations results in much more intensive student engagement in education process, gives better results, and provides a strong basis for further training. However, using their combination boosts this process and offers opportunity to achieve the maximum possible results of education. This is why the presented model gives a more advanced, flexible and stable vision of the structure of ICT competence of pre-service teachers of mathematics and informatics,

Consideration of the top characteristics of the content of ICT competence of pre-service teachers of mathematics and informatics, defined by our experiment, boosts the effectiveness of teaching and learning, and allows every student's self-realization in educational space.

The obtained results of ICT competence model can be used for the training of preservice teachers of other subjects, due to the fact that qualities, capabilities and inclinations 
are common for all disciplines, and thus it sets a profound background for effective development of ICT competence of pre-service teachers.

Further research will focus primarily on definition of principles and conditions of effective development of ICT competence of pre-service teachers of mathematics and informatics.

\section{REFERENCES (TRANSLATED AND TRANSLITERATED)}

[1] G. Bogel. "Dimensions of ICT literacy. Knowledge Quest", Journal of the American Association of School Librarians, no. 35(5), pp. 72-73, 2007. (in English)

[2] M. Wilson, K. Scalise, and P. Gochyyev. "Rethinking ICT literacy: From computer skills to social network settings", Thinking Skills and Creativity, no. 18, pp. 65-80, 2015. (in English)

[3] N. Morze, A. Kocharian, and E. Smyrnova-Trybulska. "Quality of higher education and structure of ICT competence of teachers in Ukrainian high schools", Journal of Information and Communication Technologies in Education, no. 4, pp. 61-77, 2015. (in English)

[4] O. M. Spirin "Information and communication and informatics competences as components of the system of professional-specialized competences of informatics teacher", Information Technologies and Learning Tools, no. 5, 2009. [Online]. Available: https://journal.iitta.gov.ua/index.php/itlt/article/view/183/169. (in Ukrainian)

[5] A. P. Dzhurylo, Ok. M. Shparyk. "ICT competence for secondary school teachers and students in the context of education informatization: global experience and challenges for Ukraine", Information Technologies and Learning Tools, no. 2, 2019. [Online]. Available: https://journal.iitta.gov.ua/index.php/itlt/article/view/2438/1463. (in English)

[6] A. Elizarov. "Basic ICT competence as a basis for teacher`s Internet-education". RELARN-2004, 2004. [Online]. Available from:http://www.relarn.ru/conf/conf2004/section3/3_11.html. (in Russian)

[7] O. Ovcharuk and N. Soroko, "Information and communication competence development in education system: modern studies and prospects", Information Technologies and Learning Tools, no. 1, 2016. (in Ukrainian)

[8] O. Nessipbayeva. "The competencies of the modern teacher", Bulgarian Comparative Education Society, Annual Meeting (10th, Kyustendil, Bulgaria, Jun 12-15, 2012), Part 2: Pre-Service and In-Service Teacher Training, pp. 148-154.(in English)

[9] E. Valavičius and V. Jadzgevičiene. "Survey of ICT competencies of future teachers of Mathematics and Informatics", Pedagogy Studies, no. 94, pp. 89-94, 2009. (in English)

[10] N. Morze, I. Vorotnykova. "The model of teachers ICT competence", Science Rise. Pedagogical Education, no. 10, pp. 4-9, 2016. (in Ukrainian).

[11] "ICT competency standards for teachers: policy framework". UNESCO document: 2008. 15 p. [Online]. Available:http://unesdoc.unesco.org/images/0015/001562/156207e.pdf. (in English)

[12] "National Educational Technology Standards for Teachers". Washington: International Society for Technology in Education. [Online]. Available: http:// http://www.iste.org/standards/for-educators. (in English)

[13] S. Avdeeva, O. Zaichkina, N. Nikulicheva and S. Khapaeva. "Framework for Assessing the ICT Competence of Teachers up to the Requirements of "Teacher" Occupational Standard", International journal of environmental \& science education, Vol. 11, no. 18, pp. 10971-10985, 2016. (in English)

[14] J. BriceñoMartínez, and M. Castellanos Saavedra, "Certification Programs for Training Teachers in the in ICT use", Opcion, vol. 32, no. 11, pp. 164-178, 2016. (in English)

[15] M. Weindorf-Sysoeva and S. Hapaeva. "Independent certification of a teacher's ICT competence", Bulletin of Moscow State Regional University, no. 4. pp. 74-78, 2012. [Online]. Available: http://evestnikmgou.ru/ru/Articles/View/239. (in English)

[16] K. Ford. "Competency-Based Education: History, Opportunities, and Challenges", UMUC Center for Innovation In Learning and Student Success, 20 p., 2014. doi: 10.13140/RG.2.1.4679.0885. (in English)

[17] S. Leiko. "The concept of "competence" and "competence": a theoretical analysis", Pedagogical process: theory and practice, no. 4, pp. 128-135, 2013. (in Ukrainian)

[18] O. Ovcharuk et al., "Competency Approach in Modern Education: World Experience and Ukrainian Perspectives: Library for Educational Policy", Kiev, Ukraine: "K.I.S.”, 112 p, 2004. (in Ukrainian)

[19] T. Hoffmann. "The meanings of competency", Journal of European Industrial Training, vol. 23, no. 6, pp. 275-286, 1999. (in English)

[20] The Law of Ukraine "On education", 2017. [Online]. Available: https://zakon.rada.gov.ua/laws/show/2145-19, (in Ukrainian) 


\title{
СКЛАДНИКИ ІКТ КОМПЕТЕНТНОСТІ ВЧИТЕЛІВ МАТЕМАТИКИ ТА ІНФОРМАТИКИ
}

\author{
Бирка Маріан \\ доктор педагогічних наук, доцент, професор кафедри педагогіки, психології та управління освітою \\ Інститут післядипломної педагогічної освіти Чернівецької області, м. Чернівці, Україна \\ ORCID ID 0000-0002-2891-0044 \\ marian.byrka@gmail.com
}

Сущенко Андрій

доктор педагогічних наук, професор, завідувач кафедри освіти та управління навчальним закладом Класичний приватний університет, м. Запоріжжя, Україна

ORCID ID 0000-0003-1659-4280

docanvisu@gmail.com

\section{Лукашів Тарас}

кандидат фізико-математичних наук, асистент кафедри математичного моделювання, Чернівецький національний університет імені Юрія Федьковича, м. Чернівці, Україна ORCID ID 0000-0002-1651-6402

t.lukashiv@gmail.com

\begin{abstract}
Анотація. Компетентнісний підхід нині стає все більш традиційним для української системи освіти і впроваджується на всіх іiі рівнях - від дошкільної до післядипломної освіти. У фокусі два основних поняття: «компетенція» та «компетентність», які тлумачаться по-різному в процесі навчання та викладання, що зумовлює неадекватні освітні результати. Тому глибоке розуміння цих понять дуже важливе для ефективної організації освітнього процесу. У статті ІКТ-компетенція розглядається як основна вимога, виконання якої забезпечить ефективну професійну діяльність майбутніх учителів математики та інформатики в умовах інформаційного суспільства. Належний рівень ІКТ-компетентності може значно підвищити ефективність освітнього процесу, сприяти професійному розвитку вчителя та його адаптації до змін в освітніх технологіях. Отже, визначення структури та змісту ІКТ-компетенції майбутніх учителів математики та інформатики є дуже важливим для забезпечення чіткості у визначенні результатів навчання та розвитку особистісних характеристик, необхідних для ефективного використання IКТ у подальшій професійній діяльності вчителя. У дослідженні представлено концептуальні моделі структури ІКТкомпетенції та компетентності, які долучають у фокус навчального процесу ціннісні орієнтації та якості особистості студента. На нашу думку, до структури ІКТ-компетенції, як і до ІКТ-компетентності, необхідно долучити такі критерії, як: знання, уміння, навички, ціннісні орієнтації (мотиви, стимули, цінності, інтереси та прагнення (амбіції) та якості особистості (здібності, нахили). Також у статті розглядається зміст ІКТ-компетентності майбутніх учителів математики та інформатики, який базується на основі запропонованої моделі. Дані про зміст ІКТ-компетентності були отримані з емпіричного опитування, у якому брали участь майбутні вчителі математики та інформатики та практикуючі вчителі інформатики.
\end{abstract}

Ключові слова: компетентнісний підхід; ІКТ-компетенція; ІКТ-компетентність; зміст ІКТкомпетентності; майбутні вчителі математики та інформатики.

\section{СОСТАВЛЯЮЩИЕ ИКТ КОМПЕТЕНТНОСТИ УЧИТЕЛЕЙ МАТЕМАТИКИ И ИНФОРМАТИКИ}

\author{
Бырка Мариан \\ доктор педагогических наук, доцент, профессор кафедры педагогики, психологии и управления \\ образованием \\ Институт последипломного педагогического образования Черновицкой области, г. Черновцы, Украина \\ ORCID ID 0000-0002-2891-0044 \\ marian.byrka@gmail.com
}




\title{
Сущенко Андрей
}

доктор педагогических наук, профессор,

заведующий кафедрой образования и управления учебным заведением

Классический частный университет, г. Запорожье, Украина

ORCID ID 0000-0003-1659-4280

docanvisu@gmail.com

\section{Лукашив Тарас}

кандидат физико-математических наук, ассистент кафедры математического моделирования Черновицкий национальный университет имени Юрия Федьковича, г. Черновцы, Украина

ORCID ID 0000-0002-1651-6402

t.lukashiv@gmail.com

\begin{abstract}
Аннотация. Компетентностный подход в настоящее время становится все более традиционным для украинской системы образования и внедряется на всех ее уровнях - от дошкольного до последипломного образования. В фокусе два основных понятия: «компетенция» и «компетентность», которые имеют разное определение в процессе обучения и преподавания, что приводит к неадекватным образовательным результатам. Поэтому глубокое понимание этих понятий очень важно для эффективной организации образовательного процесса. В статье ИКТ-компетенция рассматривается как основное требование, выполнение которого обеспечит эффективную профессиональную деятельность будущих учителей математики и информатики в условиях информационного общества. Надлежащий уровень ИКТ-компетентности может значительно повысить эффективность образовательного процесса, способствовать профессиональному развитию учителя и его адаптации к изменениям в образовательных технологиях. Таким образом, определение структуры и содержания ИКТ-компетенции будущих учителей математики и информатики является очень важным для обеспечения четкости в определении результатов обучения и развития соответствующих личностных характеристик, необходимых для эффективного использования ИКТ в дальнейшей профессиональной деятельности учителя. В исследовании представлено концептуальные модели структуры ИКТ-компетенции и компетентности, которые включают в фокус учебного процесса ценностные ориентации и качества личности студента. По нашему мнению, в структуру ИКТ-компетенции, как и в ИКТ-компетентности, необходимо включить такие критерии, как: знания, умения, навыки, ценностные ориентации (мотивы, стимулы, ценности, интересы и стремления (амбиции) и качества личности (способности, наклонности). Также в статье рассматривается содержание ИКТ-компетентности будущих учителей математики и информатики, которое базируется на предложенной модели. Данные о содержании ИКТ-компетентности были получены в ходе эмпирического опроса, в котором участвовали будущие учителя математики и информатики и практикующие учителя информатики.
\end{abstract}

Ключевые слова: компетентностный подход; ИКТ-компетенция; ИКТ-компетентность; содержание ИКТ-компетентности; будущие учителя математики и информатики.

\section{(c) $\mathrm{BY}-\mathrm{NC}-\mathrm{SA}$}

This work is licensed under Creative Commons Attribution-NonCommercial-ShareAlike 4.0 International License. 